\title{
SPRAWOZDANIA
}

\section{SEMINARIUM NAUKOWE „SUBSTYTUCJA - ZAMIENNICTWO - SWITCH LEKÓW BIOLOGICZNYCH”, WARSZAWA, 18 CZERWCA 2018 R.}

Dnia 18 czerwca 2018 r. na Uniwersytecie Kardynała Stefana Wyszyńskiego w Warszawie (ul. Wóycickiego 1/3) w auli im. Roberta Schumana odbyło się seminarium naukowe pt. „Substytucja - zamiennictwo - switch leków biologicznych”. Organizatorem merytorycznym wydarzenia była Katedra Prawa Cywilnego i Prawa Prywatnego Międzynarodowego Wydziału Prawa i Administracji Uniwersytetu Kardynała Stefana Wyszyńskiego w Warszawie, a partnerem merytorycznym Izba Gospodarcza „Farmacja Polska”. Wsparcie administracyjne zapewnił podmiot szkoleniowy Certified Global Education.

Celem seminarium naukowego była analiza aktualnej sytuacji prawnej, medycznej oraz społecznej w zakresie substytucji, zamiennictwa oraz tzw. switchu leków biologicznych. W związku z tym wśród zaproszonych prelegentów i słuchaczy nie zabrakło przedstawicieli nauki, praktyki oraz organizacji rządowych i pozarządowych.

Porządek obrad przewidywał siedem wystąpień tematycznych oraz jeden główny panel dyskusyjny, który odbył się zaraz po pierwszej wprowadzającej prelekcji. Wspomnianą prelekcję pt. „W jakim kierunku zmierzają dyskusje na temat leków biopodobnych" poprowadził dr hab. Marek Świerczyński, prof. UKSW, razem z mgr. Zbigniewem Więckowskim, asystentem w Katedrze Prawa Cywilnego i Prawa Prywatnego Międzynarodowego WPiA UKSW. Wystąpienie to koncentrowało się wokół kwestii bezpieczeństwa terapii oraz praw lekarza i pacjenta. Referenci zwrócili uwagę na zagadnienia związane z używaną nomenklaturą i jej znaczeniem (leki biopodobne a równorzędne a biolepsze oraz switch a substytucja). 
Następnie odbył się główny panel dyskusyjny pt. „Polityka lekowa państwa w zakresie nowych terapii a bezpieczeństwo pacjentów”. Wśród tej części seminarium naukowego, która przybrała formę debaty, swój głos zabrali następujący specjaliści: Irena Rej (Prezes Izby Gospodarczej „Farmacja Polska”), dr Grzegorz Cessak (Prezes Urzędu Rejestracji Produktów Leczniczych, Wyrobów Medycznych i Produktów Biobójczych), prof. dr hab. n. med. Grażyna Rydzewska (Kierownik Kliniki Gastroenterologii CSK MSWiA, Prezes Polskiego Towarzystwa Gastroenterologii), prof. dr hab. n. med. Jarosław Kierkuś (Klinika Gastroenterologii, Hepatologii i Zaburzeń Odżywiania Instytut Pediatrii Centrum Zdrowia Dziecka), dr hab. n. med. Marzena Olesińska, prof. nadzw. NIGRiR (Kierownik Kliniki i Polikliniki Układowych Chorób Tkanki Łącznej Narodowego Instytutu Geriatrii, Reumatologii i Rehabilitacji im. prof. dr hab. med. Eleonory Reicher), prof. zw. dr hab. Ewelina Nojszewska (Szkoła Główna Handlowa), dr Jerzy Gryglewicz (Uczelnia Łazarskiego), Mariusz Mamczarek (Naczelnik Departamentu Prawnego Biura Rzecznika Praw Pacjenta), Tomasz Kluszczyński (Senior Principal, IQVIA). Moderatorem dyskusji był dr hab. Marek Świerczyński, prof. UKSW. Prowadzony dialog koncentrował się wokół uzgodnionych tez wynikających z debaty naukowej zorganizowanej przez Katedrę Prawa Cywilnego i Prawa Prywatnego Międzynarodowego WPiA UKSW, przy wsparciu merytorycznym Izby Gospodarczej „Farmacja Polska” pt. „Polityka lekowa państwa w zakresie nowych terapii a bezpieczeństwo pacjentów", która odbyła się 5 czerwca 2018 r. na Uniwersytecie Kardynała Stefana Wyszyńskiego w Warszawie ${ }^{1}$.

Bezpośrednio po głównym panelu dyskusyjnym miało miejsce wystąpienie pt. "Co wiemy, a czego nie wiemy o lekach biologicznych, referencyjnych i biopodobnych?" prowadzone przez dr hab. n. med. Marzenę Olesińską, prof. nadzw. NIGRiR, Kierownika Kliniki i Polikliniki Układowych Chorób Tkanki Łącznej Narodowego Instytutu Geriatrii, Reumatologii i Rehabilitacji im. prof. dr hab. med. Eleonory

1 Wynikiem tej debaty jest dokument zawierający uzgodnione przez uczestników tezy. Można się z nim zapoznać pod adresem: http://bit.ly/zp19_2_oreziak1 (dostęp: 24 czerwca 2018 r.). 
Reicher w Warszawie. Zasadnicze zagadnienia, jakie przeanalizowała prelegentka, oscylowały wokół następujących pytań: 1) czy lek zarejestrowany to lek zamienny?; 2) badanie NOR SWITCH - jakie wnioski możemy z niego wyciągać, a jakich nie?; 3) czy badania dotyczące switchu oznaczają zgodę na automatyczną substytucję?; 4) doświadczenia polskie z zamianą prostych preparatów biologicznych a bezpieczeństwo zamiany skomplikowanych przeciwciał monoklonalnych?

Kolejne wystąpienie pt. „Praktyczne znaczenie wytycznych dotyczących leków biopodobnych” zostało poprowadzone przez Monikę Zientek, przedstawicielkę Ogólnopolskiego Stowarzyszenia Młodych z Zapalnymi Chorobami Tkanki Łącznej „3majmy się razem”. Wystąpienie to ukierunkowane zostało na przedstawienie trzech głównych problemów: 1) wytyczne Europejskiej Agencji Leków (EMA); 2) jakie aspekty brane są pod uwagę w dyskusji dotyczącej leków biologicznych (ekonomiczne? prawne - odpowiedzialność lekarza, szpitala, wytwórcy?); 3) stanowisko pacjentów.

W dalszym ciągu seminarium naukowego można było wysłuchać prelekcji pt. „Switch/substytucja - wytyczne, legislacja i praktyka w Unii Europejskiej: co je łączy?” prowadzonej przez Monikę Duszyńską, adwokata w Kancelarii Law for Lifesciences. W ramach swojego wystąpienia referentka przedstawiła różne stanowiska, jakie są przyjmowane w świetle dyskusji dotyczącej poruszanej problematyki: 1) stanowisko klinicystów (np. Polskie Towarzystwo Onkologii Klinicznej); 2) stanowisko farmaceutów (np. Europejskie Stowarzyszenie Farmaceutów Szpitalnych); 3) stanowiska pacjentów (np. Global Alliance for Patient Access); 4) stanowisko przemysłu (np. Polski Związek Pracodawców Przemysłu Farmaceutycznego); 5) wytyczne Pharmacovigilance (zalecenia Europejskiej Agencji Leków oraz Agencji Żywności i Leków).

Następne wystąpienie pt. „Cena a koszt leczenia” zostało poprowadzone przez Natalię Łojko, radcę prawnego w KRK Kieszkowska Rutkowska Kolasiński Kancelaria Prawna. Prelekcja ta dotyczyła: 1) zasad finansowania leków; 2) leku biologicznego a „odpowiednika” oraz „grupy limitowej”; 3) pytania: czy samo obniżenie cen leków spowoduje większą dostępność do leczenia.

W kolejnym wystąpieniu pt. „Zamówienia publiczne” prowadzonym przez Marcina Kolasińskiego, radcę prawnego w KRK Kieszkowska 
Rutkowska Kolasiński Kancelaria Prawna, słuchacze zostali zaznajomieni z: 1) praktyką Urzędu Zamówień Publicznych oraz Krajowej Izby Odwoławczej w świetle działań Narodowego Funduszu Zdrowia; 2) wielością źródeł prawa: ustawa o prawach pacjenta, ustawa prawo zamówień publicznych, Kodeks etyki lekarskiej; 3) prawem konkurencji.

Wystąpieniem kończącym wydarzenie naukowe była prelekcja pt. „Badania kliniczne leków biologicznych i co z nich wynika” poprowadzone przez prof. dr. hab. med. Michała Nowickiego, Kierownika Kliniki Nefrologii, Hipertensjologii i Transplantologii Nerek Centralnego Szpitala Klinicznego Uniwersytetu Medycznego w Łodzi. Prelegent ten skoncentrował swoją uwagę przede wszystkim na rodzajach badań klinicznych (badania typu superiority, non-inferiority i equivalence) oraz na pytaniu, czy na ich podstawie można stwierdzić, że lek biopodobny jest lepszy od referencyjnego.

Wszystkie wygłoszone prelekcje oraz główny panel dyskusyjny cechowały się wysokim poziomem merytorycznym oraz praktycznym. Wydźwięk poruszanej problematyki oraz zaprezentowanych tez, niejednokrotnie, prowokował do ożywionej dyskusji, która swoim poziomem oraz klarownością nie odbiegała od głównego wydarzenia. Panująca na seminarium atmosfera sprzyjała prowadzeniu dyskursów naukowych nie tylko w ramach wspomnianych już dyskusji panelowych, lecz także kontynuowaniu ich w kuluarach, gdzie można było usłyszeć wiele ciekawych i odważnych spostrzeżeń oraz twierdzeń.

Ostatnie chwile seminarium naukowego zostały zarezerwowane na podsumowanie i zakończenie obrad. Przedstawiciel organizatorów (mgr Zbigniew Więckowski) podziękował wszystkim przybyłym za aktywne uczestnictwo w zorganizowanym wydarzeniu oraz wyraził nadzieje, że rozpoczęta inicjatywa naukowa dotycząca problematyki leków biologicznych będzie dalej kontynuowana. Zaprosił wszystkich zainteresowanych na kolejną już trzecią konferencję naukową dotyczącą leków biologicznych, która tradycyjnie odbyła się 7 grudnia 2018 r.

Bartłomiej Oręziak*

* Uniwersytet Kardynała Stefana Wyszyńskiego w Warszawie. 